\title{
A CONCEPTUAL FRAMEWORK TO APPROACHING LATE ANTIQUE VILLA TRANSFORMATIONAL TRAJECTORIES
}

\begin{abstract}
The mutation of the villa in the Western Roman Empire is a key element to our understanding of the transformation of the rural landscape between Late Antiquity and the Early Medieval Period. The archaeology of this transitional phase has long been identified and has been dated to between the 3rd century in some regions and as late as the 6th and 7th centuries and in other areas; however, it is only in the last 20 years that work has begun to examine the phenomenon in detail, with a number of regional studies emerging and a few larger but primarily non-empirical studies undertaken. Despite this, an overarching unified conceptual approach is lacking with little or no attention payed to the trajectories of individual sites. This paper intends to develop and demonstrate a new approach to the phenomenon of villa change, establishing a clear classification system, augmenting the work done by Chavarría (2004) and Ripoll and Acre (2000), categorising the different elements of transformation and applying this to the development of site trajectories It will also discuss the basis and feasibility of a standardised terminology to refer to these diverse features, replacing the biased catch-all phrase 'squatter occupation'.
\end{abstract}

Keywords: Rural, Transformation, Late Antique, Villa, Early Medieval

\section{James Dodd}

Vrije Universiteit Amsterdam j.a.l.d.dodd@ @vu.nl

DOI: $10.14795 /$ j.v6i1.359

ISSN $2360-266 \mathrm{X}$

ISSN-L 2360 - 266X
$\mathbf{T}$ he villa was the basic building block of the Roman rural economy, providing the foundation for a whole host of economic activities and social displays. The entire economic basis of surplus agricultural production, rural taxation, landownership and food supply were structured and dominated by the villa system (Roymans and Derks 2011, 1-4). Socially, the villa system allowed the landed elites a significant degree of social expression and a forum to articulate their Romanitas to some degree through the addition of non-functional and monumentalising features ${ }^{1}$.

Between the $3^{\text {rd }}$ and $6^{\text {th }}$ centuries $\mathrm{AD}$, the villa network suffered severe dislocation and significant socio-economic change ${ }^{2}$. The hybrid classicising rural society of the Roman world (Woolf 1998; Crowley 2011) adopted more utilitarian and functional styles of occupation, abandoning Romanising socio--cultural conventions of architecture and identity. This dislocation and change is characterised by the disposal of the socio-economic conventions of Romanitas in favour of more utilitarian and functional styles of occupation, and is framed within an increase of rural abandonment rates across various areas of the Western Empire ${ }^{3}$ and occupation contraction at many sites and notably in some regions, the reoccupation of certain sites by groups of immigrants ${ }^{4}$. The breakdown of the villa landscape is perceptible across

\footnotetext{
SLOFSTRA 1991, 179-182; SMITH et alii 2016, 33-37; HINGLEY 2005, 87-89.

LEWIT 2003, 260-261; LEWIT 2004, 251-252; CHAVARRÍA 2004, 67-68.

cf. HEEREN 2015, 280-283; LENZ 1998; CHAVARRÍA 2004, 71.

4 HEEREN 2017, 158-159; CHAVARRÍA 2007, 69-78.
} 
both halves of the Roman Empire. Archaeologically, this breakdown is visible in the west through the abandonment and re-use of high-status architectural elements for other purposes and the apparent 'decay' of the villa fabric. This transformation occurs at different times in different parts of the Roman West during Late Antiquity, but its first appearances are in Britain and along the Lower Rhine at the end of the 2 nd and the very beginning of the 3rd century $\mathrm{AD}^{5}$. The redefinition of social space and the adoption of new lifestyles are key elements in the development of Roman rural buildings in landscapes of later centuries and represent a transitional phase between the world of the hierarchical state and a more subsistence based and less hierarchical system. This redefinition, together with migration, regionalisation and architectural transformation have all left their imprint on the later development trajectories of villa complexes. The shift in rural occupation is part of a much wider canvas of change; evidence indicates that transformation occurs in both urban contexts ${ }^{6}$ and military installations ${ }^{7}$ throughout Late Antiquity.

This paper will sketch out a conceptual framework for classifying villa transformation and so-called 'post-villa activity'. Firstly it will establish a categorisation system based on archaeological architectural features and material culture and secondly will put forward a more integrated model for plotting the trajectories of change and the transformation of space at individual villa sites in a similar manner to early Roman period pioneered by Habermehl ${ }^{8}$. Although classification systems are not new in relation to villa transformation, this system differs in its application. Operationally, it integrates both cross-regional comparisons and the application of a standardised system between regions as well as aligning the terminology to provide a better foundation for further analysis. This provides a basis for the development of larger, more integrated comparative models within a GIS dataset to map change on a more analytical level.

\section{FROM 'SQUATTING' TO TRANSFORMATION: THE VILLA RESEARCH CONTEXT}

Traditionally, the transformation of the villa and the presence of 'post-villa activity' has been severely neglected, serving only to support narratives of 'Decline and Fall' in the Gibbonist tradition ${ }^{9}$. Consequently, until the 1990s, little or no significant analysis had been addressed at the end of occupation. When transformation was addressed it was dismissed simply as squatters inhabiting the ruins, characterised by 'messy' occupation ${ }^{10}$. Older site reports tend to employ loaded language to describe the processes of rural transformation and abandonment in Late Antiquity, utilising a wide range of related phrases and words, dismissing occupation layers as 'type de habitat précaire', 'de campements', 'wretched' and 'rude'11 or in English, the

\footnotetext{
DODD 2014; VAN OSSEL 1992

6 SPEED 2014; RODGERS 2011

WILMOTT 1997, 203-24; COLLINS 2017, 212-215

HABERMEHL 2014, 54-55

cf. LEWIT 2001

WEBSTER 1969, 222, cf. LEWIT 2001, 261-262; cf. LEWIT 2004, 251-252;

cf. PETTS 1997, 103-105

${ }_{11} c f$. LEWIT 2005, 254; $c f$. MATTINGLEY 2006, 534
}

overarching term 'squatter occupation'12. Individual site evidence has suffered from this disparaging bias. There are serious deficits in the later stratigraphy of sites across the Roman West ${ }^{13}$ with later material often ignored wholesale or cleared off without extensive record in the search for highstatus remains ${ }^{14}$. Where recording has taken place many features have suffered from extremely vague descriptions, especially in the description of poorly dated habitational features such as subdivision of walls or occupation debris ${ }^{15}$ and non-identifiable burials ${ }^{16}$.

This issue has been further compounded by a clear historicising agenda. Destruction levels and 'messy' occupation at villa sites have been traditionally associated with historical events and attempts to make destruction horizons match up with historically attested phases of barbarian raiding are commonplace. For example, apparent $4^{\text {th }}$ century destructions in Britannia Prima was traditionally associated with the Barbarian Conspiracy of $367 \mathrm{AD}^{17}$ despite the evidence suggesting that this is not the case. This association is not confined to Britain as Spain ${ }^{18}$ and Northern Gaul $^{19}$ have suffered the same approach. It is, however, now clear that destruction horizons are very difficult to pin down to individual events and re-evaluation of many sites has demonstrated that layers initially identified as destructions may prove to be something entirely different. This approach was supported by the assertion that transformation must be the product of barbarian occupation at these sites. This bias framework fitted into the historicising narrative of decline and fall and was aligned with older theoretical frameworks surrounding Imperialism ${ }^{20}$. It is, however, now clear that destruction horizons are very difficult to pin down to individual events, and re-evaluation of many sites has demonstrated that layers initially identified as destructions are something else entirely ${ }^{21}$.

The traditional narrative was supported somewhat by the assertion that transformation must be the product of barbarians 'squatting' in the ruins of these once-grand buildings. Barbarians are assumed to be responsible for postRoman occupation at many sites ${ }^{22}$ with habitational has been dismissed as the construction of 'habitations sommaire' and reuse by 'familias visigodas' ${ }^{23}$ or 'Saxon marauders'24.

The revisionist revolution of the 1970s and 1980s has favourably affected the development of villa studies. This shift has prompted more engagement with the transformation of the villa landscape beginning with Rivet (1969) and Percival (1976) who began to examine elements

\footnotetext{
2 WHEELER/WHEELER 1936, 206; BALMELLE 2001, 158; RASCÓN et al. 1991,197

13 for two examples, LIVERSAGE et alii 1973; SÁNCHEZ 1997

4 for example, PAYNE 1897; KOETHE 1940; HETTNER 1893

5 GARCÍA GELABERT/GARCÍA DÍEZ 1997; ORETEGO 1977

WRIGHT 1941; NASH-WILLIAMS 1953

WEBSTER 1969, 223-230; cf. BRANIGAN 1971, 115-116; cf. BRANIGAN 1972, 120-121

18 GORGES 1979, 43-45; TARACENA 1950; RAMOS FLOQUES 1960; BLÁZQUEZ/GARCÍA-GELABERT 1993

19 GRENIER 1934, 890-950; AGACHE 1978; WIGHTMAN 1985, 219-222.

cf. VAN OSSEL/OUZOULIAS 2000, 133-135

20 LEWIT 2001, 34-35

for examples in a military context, see HEEREN 2016

RASCÓN et alii 1990, 188-193

GARCÍA GELABERT/GARCÍA DÍEZ 1997, 53

PAYNE 1897, 69
} 
of continuity in serious detail. Large scale regional studies in Northern Gaul ${ }^{25}$, Spain ${ }^{26}$, South-East Gaul ${ }^{27}$, Italy ${ }^{28}$ and Britain $^{29}$ have greatly contributed to our understanding of the nature of rural change, and it is now possible to say that every part of the Western Empire, with the possible exception of North Africa, was affected by this change.

Academic work has unravelled much of the bias evident in previous literature and begun to rehabilitate the phrase 'squatting' in the archaeological record ${ }^{30}$. The theoretical framework for most of this is complete with various studies developing new contextual themes ${ }^{31}$. Petts (1997) and Lewit (2005) have concluded that the phenomenon represents the reorganisation of personal and social space within the villa in the Western provinces during the $4^{\text {th }}$ and $5^{\text {th }}$ century, in the light of increasingly irrelevant Roman social etiquette as the need and desire for displays of opulent and ostentatious cultural homogeneity amongst members of villa-owning elite declined. Ellis (1988) has broadly supported this theme, arguing for a dramatic shift in occupation patterns that show the transitional nature of Late Antiquity in which the classical peristyle house fell out of use and was abandoned in favour of more egalitarian habitations. This manifested itself through the subdivision of rooms and the use of former high-status rooms for utilitarian functions ${ }^{32}$. Many of Ellis' case studies come from the Eastern Empire where other factors, not present in the West, are at play in the changing milieu of Late Antiquity, primarily 'soukification'33. Ellis also draws attention to the existence of a growing inequality of habitation; a small number of buildings showing overwhelming surplus investment whilst others show evidence of mutation. This is a trend also visible in $4^{\text {th }}$ century Spain $^{34}$. This process has rejected loaded phrases such as 'wretched' and 'rude' and above all, abandoned the use of the word 'squatting' to describe features and deposits to view transformation as a phase within its own rights, as a long-term phenomenon tied to socio-economic change, and not the result of barbarian 'sojourners' ${ }^{35}$ reusing the ruins. It is also worth noting that comparable trends in occupation in other classes of sites appear in the Late Roman period. The same features are visible in military sites, where industrial transformation and wooden constructions are common ${ }^{36}$, urban sites $^{37}$ and religious sites ${ }^{38}$. These similar changes, with increasing reliance on wooden construction and nonRoman forms of construction, had they been uncovered in villas, would have been characterised as 'habitats sommaire' and dismissed.

\footnotetext{
25 VAN OSSEL 1992; GANDINI 2008.

26 CHAVARRÍA 2007; RIPOLL AND ACRE 2000; BROGIOLO/ CHAVARRÍA 2008.

27 RÉCHIN 2006; SCHNEIDER 2007; HEIJMANS/GUYON 2007; RAYNAUD 2018.

28 CASTORAO BARBA 2014; 2016.

29 DODD 2014.

30 LEWIT 1991; PETTS 1997; CHRISTIE 2004.

31 VAN OSSEL/OUZOULIAS 2000; CHAVARRÍA 2004; LEWIT/

CHAVARRÍA 2004; RIPOLL/ACRE 2000.

32 MUNRO 2010; FLEMING 2012; CHAVARRÍA 2004

33 LANDSTÄTTER/PÜLZ 2007.

${ }_{34}$ CHAVARRÍA 2004; 2007.

35 O’NEILL 1933, 138.

36 COLLINS 2012, 171-176; 2017, 213-215.

37 SPEED 2014; RODGERS 2011; WHITE 1990.

38 RAHTZ/HARRIS 1956; HENRICH 2010.
}

Despite the advanced theoretical state of the field, a unified conceptual framework is still somewhat lacking. The majority of scholarship now examines the end of the villa environment as a long term phenomenon, influenced by inherent flaws in the economic structure of the Late Roman economy and there is consensus that rural change is part of a wider transformation of socio-economic display. Despite this, a standardised framework rooted in a standardised terminology and framework is lacking, hampering crossregional comparisons and high level analysis. A more integrated approach to transformation, rooted in the archaeological data will be put forward in this paper.

\section{KEY CONCEPTS}

Before developing this conceptual framework, several parameters of definition are required. Both the term villa and the phrase villa transformation require definition within the context of this study.

The term villa is deeply problematic. The word has been in use since the Classical period and has been seriously confused and misrepresented by 150 years of different perspectives, poor definitions and partial excavations of villa sites. It has been argued over, defined and counterdefined since the advent of early archaeology in the $18^{\text {th }}$ and $19^{\text {th }}$ centuries. Willems ${ }^{39}$ has deftly summed up the terminological situation, stating 'exactly what constitutes a Roman villa is a subject that will probably be debated forever...'

The Latin concept villa rustica refers to a type of rural residence favoured by the Roman elites, and the use of the term is most in vogue during the Republican and Early Imperial periods ${ }^{40}$. The term, however, appears in a wide variety of spatially and temporally diverse sources, often in a frustratingly vague and inconsistent way ${ }^{41}$. It was applied to anything from elite rural retreats to the estate centres of large latifundia by different writers at separate times, and is often difficult to pin down through allegory and metaphor ${ }^{42}$. This is further confused when considering the vast climatic variation and differing cultural traditions which make it impossible to apply a Mediterranean-centric Latin concept to the entire rural organisation of the Western Empire.

Archaeologically, the term has tended to refer to rural dwellings demonstrating some element of Romanitas. This definition, drawing on the Latin term, seeks to take elements of the ancient descriptions whilst ignoring the literary connotations. This morphological approach has inevitably led to the term being applied to any rectangular rural main house, especially in the Northwest provinces ${ }^{43}$. The dichotomy between the archaeological evidence and the literary terms has led to two diverging schools of thought; first an 'Italic model', rooting villas in a historical interpretative model ${ }^{44}$ (and secondly, an archaeological model, viewing villas from within a landscape-archaeological perspective ${ }^{45}$. This perspective has led to the development of a socio-cultural definition of the villa. In some cases, the

\footnotetext{
WILLEMS 1981, 112

CATO, De Agricultura 1.4.1; VARRO Res Rusticae, 3.2.10.

PERCIVAL 1976, 14-15; RIVET 1969, 178-179.

DARK 2005.

cf. HABERMEHL 2014, 17-18; PERCIVAL 1976, 13.

RIVET 1969, 178-182; PERCIVAL 1976, 119-144; cf. SLOFSTRA 1983, 87.
}

ROYMANS/DERKS 2011, 1-4; cf. HINGLEY 1989, 3. 
villa has been stripped of its classical veneer and essentially reduced to a form of glorified farmstead ${ }^{46}$ whilst in others, it has been assumed to be the primary driver behind rural production and elite expression ${ }^{47}$. Abstract evolution models and settlement hierarchies have been developed around this form of definition ${ }^{48}$, with these socio-economic associations and presumptions becoming the defining characteristics of a villa.

This study will approach the villa within this wellestablished tradition, rejecting the literary definitions in favour of an archaeologically grounded definition. It will define the term within a more practical framework, approaching it from a more rounded, morphological viewpoint, a definition used in a large number of works ${ }^{49}$. This definition assesses rural structures based upon their architectural morphology but also with the understanding that these buildings are probably owned by the elite of rural society or, at the very least, their agents. The defining characteristics for a villa site in this study are relatively simple. Architecturally, consideration as a villa site requires rectangular construction in stone, or partially in stone, as a primary element. This form of construction must however be combined with monumentalising architectural elements such as porticos, verandas, ornamental pools, courtyards and monumental approaches with a minimum number of small rooms. These buildings must additionally demonstrate some combination of non-functional or luxury internal features through the presence of hypocausts, interior décor, baths and sometimes mosaics, tessellated pavements and luxury decoration such as marble, statuary and fountains.

These buildings are usually part of an estate centre, consisting of a monumentalising main house and a series of ancillary production, storage and processing structures. The structures are sometimes physically connected to the main house through a separate wing but, alternatively, can be standalone structures within a nucleated settlement. In short, the villa is being defined as the main house of an estate centre, of which one building or more must demonstrate some form of additional non-functional features indicating a degree of investment of surplus disposable capital intolanded assets $^{50}$. This level of investment automatically indicates that these structures are the preserve of the wealthier classes of society and this project will adhere to this, assuming that the villa was the residence of elite members of society and their agents.

Related to this are two other terms, key to this project and defined within its framework. The villa landscape is an environment in which villas dominate both socio-economic life and the physical fabric. It refers not just to the numerical superiority of villa sites but also the perception of these structures by local rural populations ${ }^{51}$. This is opposed by a non-villa landscape; an environment in which more traditional forms of occupation constitute the majority of rural sites. This implies a more traditional form of landscape

\footnotetext{
46 REECE 1988, 49.

47 SLOFSTRA 1991, 175-177.

48 SLOFSTRA/BRANDT 1983; HODDER/MILLET 1980.

49 for example; LEWIT 2001, 260; CHAVARRÍA 2007, 32-36; VAN OSSEL 1992, 39-44; HEIMBERG 2002/2003, 68-69; cf. HINGLEY 1989, 2-4.

50 HINGLEY 1989, 45-46.

51 ROYMANS 1996, 61; ROYMANS/DERKS 2011, 3.
}

organisation and settlement hierarchy, although this does not preclude the presence of an occasional villa or cluster of villas.

The phrase villa transformation refers to the archaeological visible changes to the physical fabric of the Roman villa during Late Antiquity. In this definition, it will refer to three broad categories of activity. Reuse, the 'reutilisation of buildings and their facilities', reoccupation, the repeated use of these structures by inhabitants living onsite after a period of abandonment or reduced occupation, and altered function, the reoccupation or reuse of buildings for purposes other than originally intended. These forms of occupation, all of which manifest themselves at villas between the $3^{\text {rd }}$ and $6^{\text {th }}$ centuries $\mathrm{AD}$, and are archaeologically visible in a series of diverse but related phenomena. These features are often messy in comparison to earlier occupation, reusing and altering earlier and often high status elements of the physical fabric. They include a wide variety of different types of activity that will be dealt with later, but often the hints of occupation are very slight and activity must be inferred from very little evidence.

\section{CONCEPTUAL FRAMEWORK}

In line with previous studies, this system itemises the larger term villa transformation into smaller, more manageable categories set within the framework of a feature-based classification system. This division is not new; classification systems have been an important part of transformation studies since the beginning of modern research into the topi ${ }^{52}$. Despite their ubiquitous use, several problems are inherent in existing systems. In a majority of cases, classification is not fully developed ${ }^{53}$ with little or no engagement with the stratigraphic features. Highly regionalised systems are also problematic ${ }^{54}$ with little or no applicability to other areas. Generally studies have tended to deconstruct the evidence of transformation into several broad categories; productive, habitational, cultic and funerary. This system works within this convention whilst integrating a new category: fortification, a form of transformation which has not received significant quantification but has been superficially examined ${ }^{55}$.

The primary problem however is the lack of standardisation between competing classification systems. One previous paper has even called for further codification and standardisation ${ }^{56}$. Classification used by previous studies has proved rather vague in terms of archaeological features and material culture, with the exception of Van Ossel (1992), although this work is not without significant issues. The classification system put forward here rectifies this, establishing more rigorous categories, expanded and augmented with a standardised terminology for individual classes (key terminology laid out in Figures 6) based upon the Forum on Information Standards in Heritage (FISH).

\footnotetext{
2 VAN OSSEL 1992.

RIPOLL/ARCE 2000, 70-95; CASTRORAO BARBA 2014, 261-262; CHRISTIE 2018.

54 CHAVARRÍA 2004, 76-85; 2007; VAN OSSEL 1992, 127-142; DODD 2014; CASTRORAO BARBA 2016.

55 VAN OSSEL 1992, 161-165; VAN OSSEL/OUZOULIAS 2000, 143-145; HEEREN 2018, 141.

${ }_{56}$ RIPOLL/ARCE 2000, 71, 99.
} 


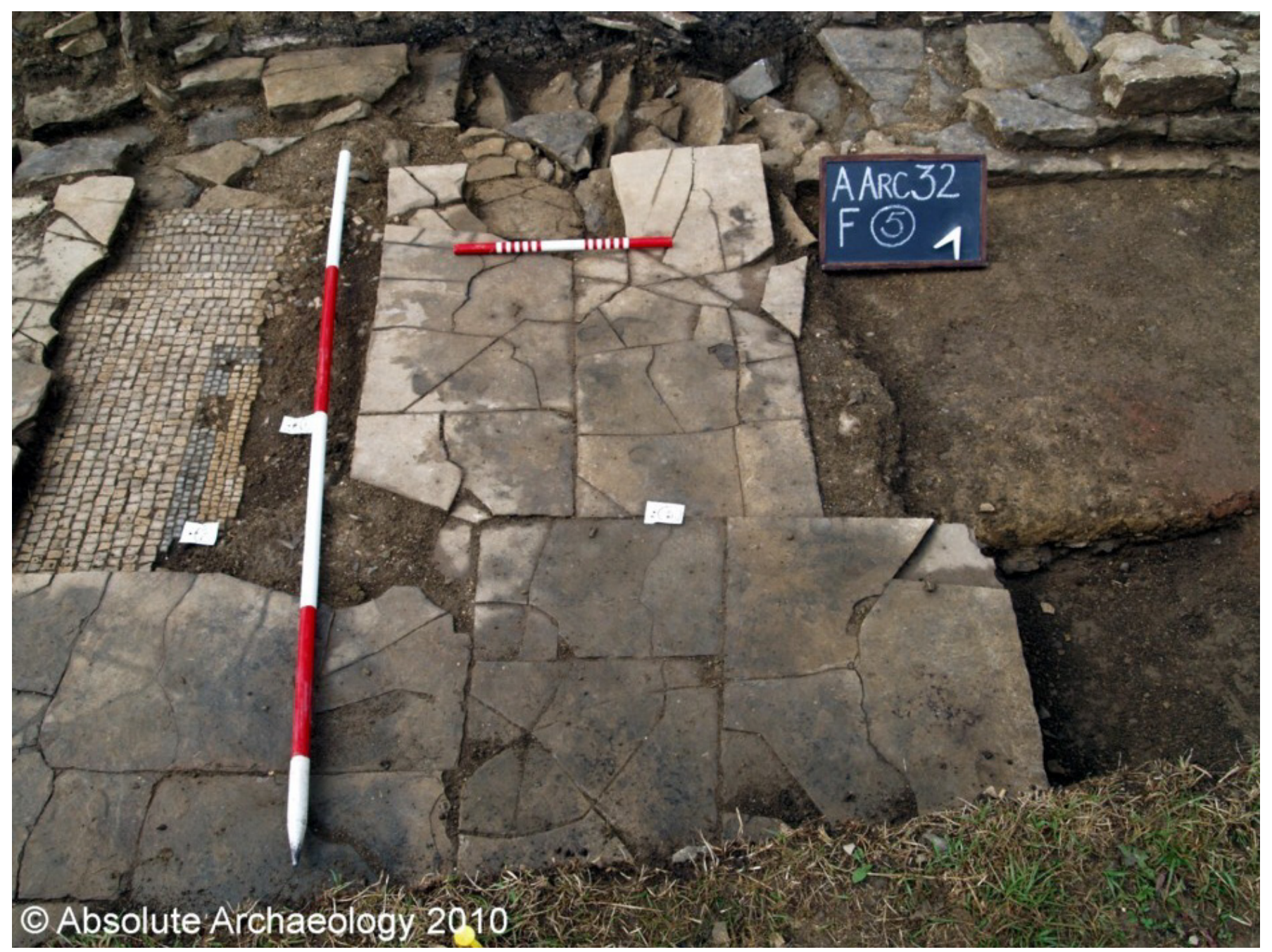

Fig. 1. An example of habitational transformation. A rough flagstone floor laid over an earlier mosaic at Butleigh (Absolute Archaeology ${ }^{60}$ )

\section{Habitational Transformation}

Habitational transformation refers to the presence of continued domestic occupation or reoccupation of the physical fabric of the building. It is almost always defined within the framework of a change in building styles with less emphasis placed upon Romanising elements and a dispensation with classicising architecture ${ }^{57}$.

Physically, it is characterised by several trends. It can be divided into two distinct forms; a reversion to timber post-built structures ${ }^{58}$, often argued to have been related to the presence of immigrants ${ }^{59}$ and the renovation of existing buildings in a different style. New walling, utilitarian flooring in addition to ephemeral features, such as hearths or rubbish dumps (for example in figure 1) are associated with domestic transformation and are found in habitational contexts across many Late Antique villas. In many cases, the evidence for this can be extremely vague. This is the product of a variety of factors including excavation biases and site formation process and the features themselves are often only very broadly datable. Elements of habitational transformation often possess multi-faceted purposes. For example, apparently domestic hearths may be found in demonstrably industrial contexts. In cases such as this, the

\footnotetext{
CHAVARRÍA 2004, 80-81.

58 VAN OSSEL 2006.

59 cf. HEEREN 2017, 160-163.
}

evidence can be interpreted as belonging to a different class of transformational activity. ${ }^{60}$

\section{Productive Transformation}

Productive transformation relates to the alteration or reoccupation of villa buildings and the wider villa terrain for economically productive activities. This form of transformation has long been noted as a key element within the Late Roman rural economy ${ }^{61}$ and forms part of a wider trend of increasingly diverse industrial production at villa settlements in Late Antiquity, especially in the NorthWestern provinces.

Morphologically, it is characterised by the alteration of a building, room or zone for the installation and use of industrial, artisanal or productive facilities, including storage zones. This class represents the clear modification of former structures into manufacturing zones and encompasses everything from small-scale ceramic production, for example at Bruyelle ${ }^{62}$ to large-scale grain processing and storage, for example at Hambach 21 (for an example, see figure 2). This process both includes the alteration of formerly highstatus residential zones, for example at Torre Llauder as well

\footnotetext{
${ }^{60}$ https://archaeologydataservice.ac.uk/library/browse/issue. xhtml? recordId=1118958\&recordType=GreyLitSeries.

${ }_{61}$ LEWIT 1991.

62 BRULET 2009, 305.
} 


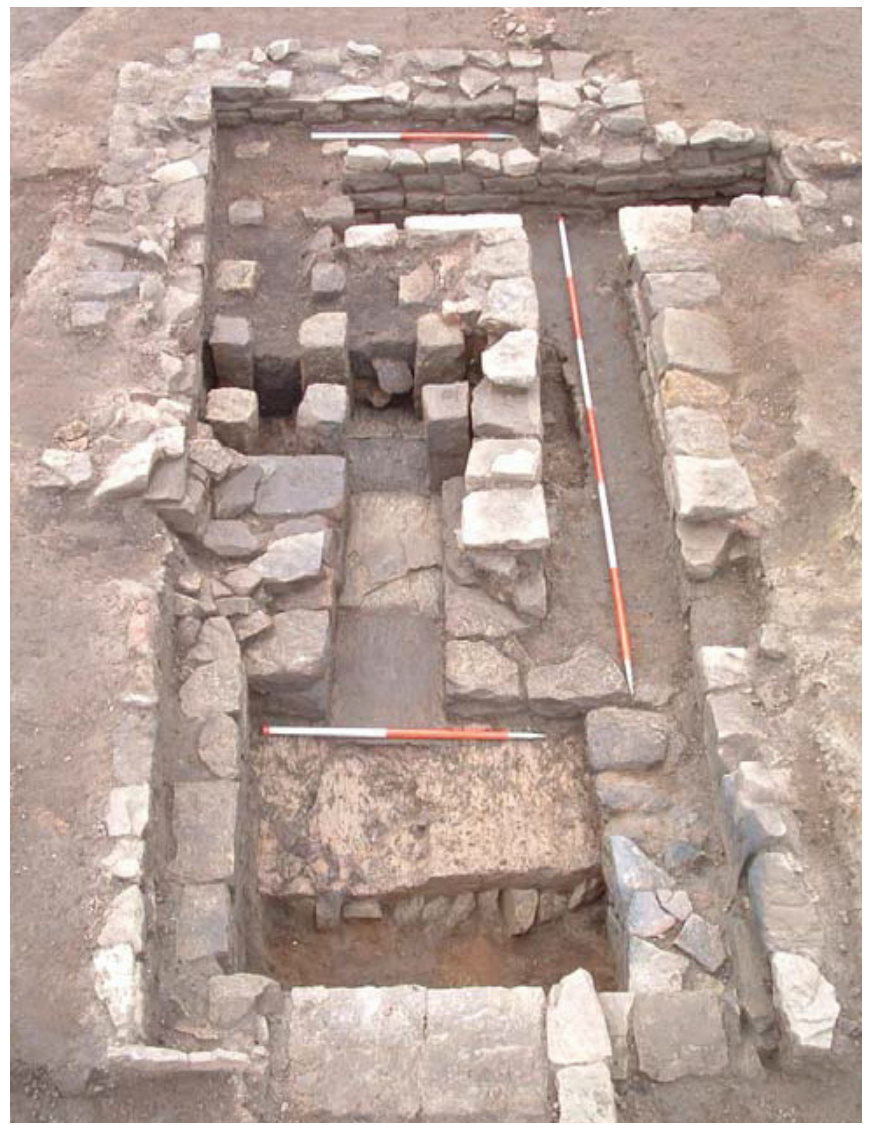

Fig. 2. An example of productive transformation. The conversion of a bath house into a T-shaped grain drier at Ingleby Barwick (Willis and Carne 2013, Plate A2).

the movement of productive activity from main buildings to post-built structures on the villa terrain, for example at Minster-in-Thanet. In some cases, regional industry developed from newly founded artisan production at groups of villas, with the Hambach glass industry acting as a regionally vibrant manufacturing hub throughout the $4^{\text {th }}$ century. Archaeologically, they tend to be most visible when related to large-scale surplus production rather than smallscale processing; at which level there can be some interface with domestic level agricultural use.

\section{Funerary Transformation}

The use of villa sites for burial purposes is well attested in Late Antiquity and the Early Middle Ages ${ }^{63}$ with a high frequency of appearance in all regions of the Western Empire. This phase of reuse is generally concentrated towards the end or after occupation ends is difficult and complex to contextualise. It includes both small-scale groups of burials or individual graves as well as large developed cemeteries and is not temporally or spatially limited within the villa complex. Burials are generally assumed to date to the end of the Roman period or immediate sub-Roman period, although much greater evidence has come to light in recent studies ${ }^{64}$ highlighting the evidence for funerary use into the Early Medieval and High Middle Ages, especially on

\footnotetext{
${ }_{63}$ For a number of examples see, CHAVARRÍA 2004, 81-83; CHAVARRIA 2018; LEWIT 2003, 261-262; PELLECUER/POMARÉDES 2001, 524-525; LE MAHO 1994, 10-24.

${ }^{64}$ cf. CHAVARRIA 2018.
}

\section{Mediterranean sites.}

Funerary use is often very difficult to quantify, with its scale poorly recorded due to the ephemeral nature of many burials, and an excavation bias against such features. Many of these graves are circumstantial, easily destroyed by careless excavation, or are in poor states of survival. Little post-excavation analysis has been done on the material and many larger cemeteries, especially in North-Western Europe remain unpublished.

\section{Cultic Transformation}

Similar in nature to the reuse of rural structures for funerary purposes, the transformation of rural buildings for religious purposes is well documented, especially in the Mediterranean region ${ }^{65}$. It is well understood with a developmental trajectory beginning with private chapels developing from the $4^{\text {th }}$ century onwards ${ }^{66}$ and in some cases represents the conversion of large portions of the house into religious zones.

Conversion into religious structures can take a number of diverse forms, from the conversion of a room to a house-chapel such as the case of the Villa Fortunatus ${ }^{67}$

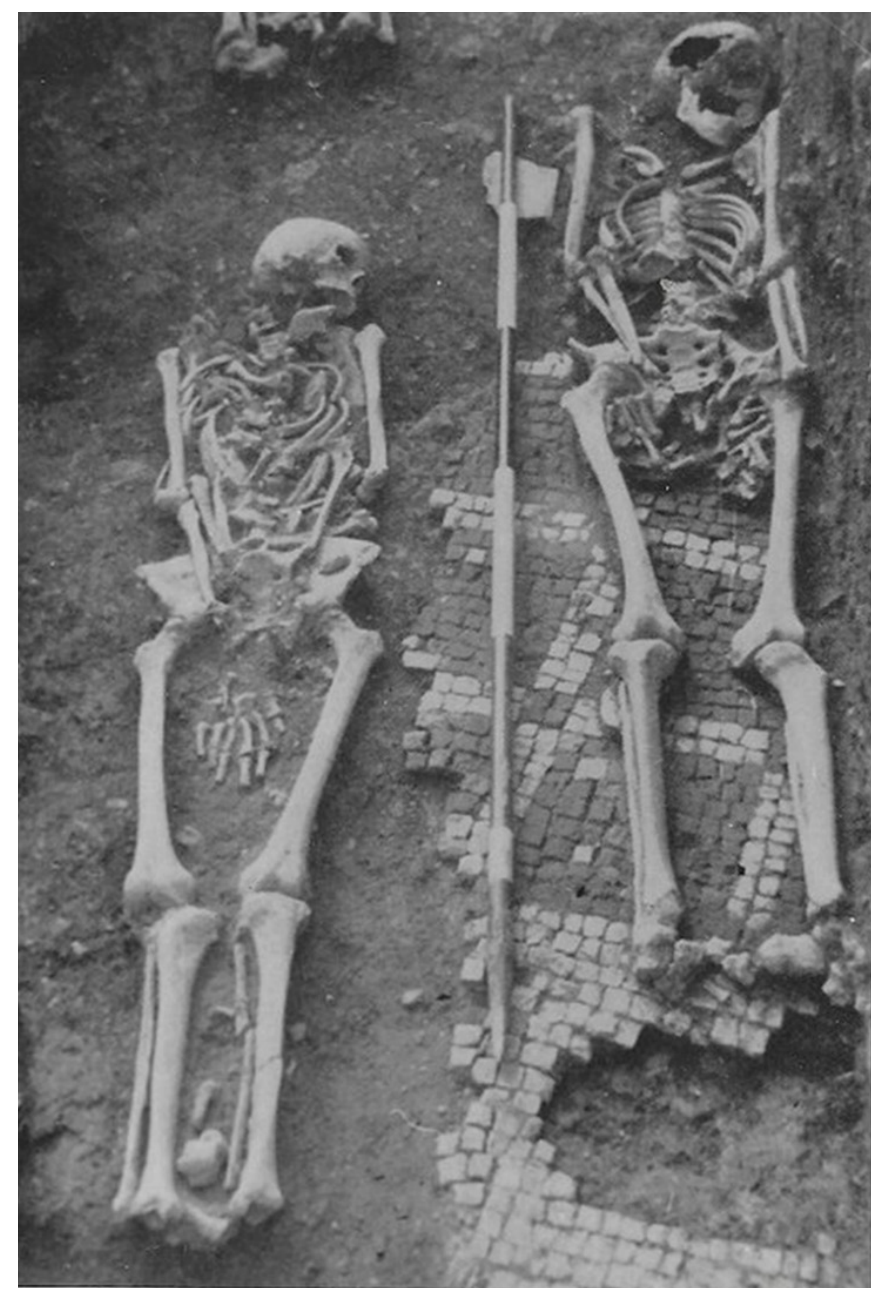

Fig. 3. An example of funerary use. Part of a larger sub-Roman cemetery at Southwell (Daniels 1966).

5 CHAVARRÍA 2004, 83-85; RIPOLL/ARCE 2000, 74-88; BOWES 2001, 324-328; BELL 2007 amongst a great deal of other literature.

66 RIPOLL/ACRE 2000, 74-75.

67 PUERTAS 1972. 


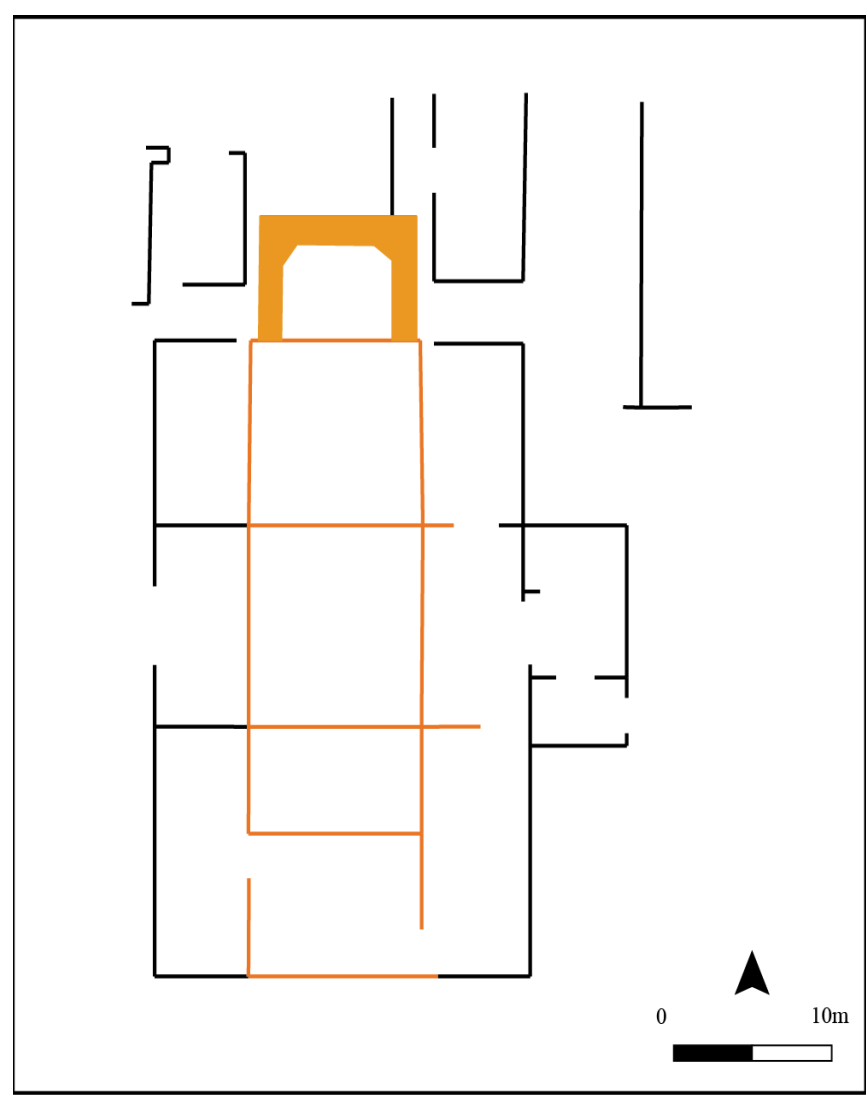

Fig. 4. An example of cultic reuse (highlighted in orange). The insertion of a Christian basilica into the Villa Fortunatus (Dodd, after Duval 1982, 37, fig. 3). Drawn in Adobe Illustrator.

and Lullingstone ${ }^{68}$ to the reuse of abandoned buildings or squatter structures such as at Bradford-on-Avon ${ }^{69}$ and Echternach ${ }^{70}$ or the construction of entirely new buildings for example at Torre Del Palma ${ }^{71}$. There is also evidence of the conversion and development of villas sites into monastic communities $^{72}$, although this often develops through private house-chapels from the late $4^{\text {th }}$ century onwards ${ }^{73}$, for example at Plassac and later at Torre Del Palma. The installations themselves vary greatly in size and shape, with no clear architectural evidence. They are often difficult to discern without explicit evidence ${ }^{74}$ although it notable that in Southern Europe, especially Iberia, religious reuse of villas is much more visible.

\section{Fortification Transformation}

The fortification of villa sites is a generallyless common phenomenon and tends to be regionalised in specific areas, such as Pannonia ${ }^{75}$, parts of the German provinces ${ }^{76}$ and North Africa ${ }^{77}$. Fortified villas in Europe have generally been examined within the tradition of research on fortified towns and military installations ${ }^{78}$. Very little work has been done to 68 MEATES 1979.

69 CORNEY 2002, 2003.

70 METZLER/ZIMMER/BAKKER 1981, 29-45.

71 MALONEY/HALE 1996.

72 PERCIVAL 1997.

73 RIPOLL/ACRE 2000, 86-88.

74 cf. MONTFRIN 1998.

75 CHRISTIE 1992, 320.

76 VON PETRIKOVITS 1971, 180-183

77 MATTINGLEY 1995, 194; RIND 2009, 53-65.

78 JOHNSON 1984; BRULET 2017, 53; HENRICH 2016/2017, 177-187. integrate a framework for fortified villas into a more general study of rural transformation. Most studies of fortified villas are small-scale and superficial, focusing upon either very specific elements ${ }^{79}$ or very broad-brush studies ${ }^{80}$.

Morphologically, fortification is defined from an architectural position, simply as the presence of defensive elements at a site. This naturally encompasses a large group of sites with diverse elements, including both putative and truly fortified construction. It includes features such as stone defences, palisaded enclosures and regionally significant features. These features, some bearing the hallmarks of military architecture include both the presence of poorly understood and ill-defined Speichertürme, traditionally viewed as a fortified grain storage silo and burgi, small forts or watch-towers in Northern Gaul and Germany.

One of key concepts not covered in the sequence of transformation covered above is the process of abandonment. Abandonment is inevitably the endpoint for most Roman rural buildings, however, in what for, and how long this takes is matter of some discussion. Traditionally, studies dealing with the transformation of Roman rural settlements have brushed very lightly over the concept and theory of abandonment. The process of site abandonment has been addressed on the macro scale ${ }^{81}$; however the primary focus of many studies has been directed at isolating transformation from abandonment ${ }^{82}$ with very little work directed towards a unified theoretical or methodological framework. Instead, the focus has rather been directed towards the transformation of sites $^{83}$, or establishing cases of continuity between Roman and Early Medieval occupation ${ }^{84}$.

Practically, Roman archaeology has tended to implicitly follow the definition of abandonment laid out by Schiffer ${ }^{85}$; 'the process whereby a place - an activity area, structure or entire settlement is transferred to the archaeological record'. Despite its somewhat ubiquitous use, this definition is flawed when related to the afterlife of the Roman villa. Recent work, especially in New World Archaeology, has highlighted the impossibility of a clear and simple definition of abandonment ${ }^{86}$. In addition, research has cautioned against the default position of the so-called 'Pompeii Syndrome'87 which assumes little or no use of a site after the end of formal occupation and can only be realistically applied to a small minority of sites destroyed beyond all use or recovery.

Abandonment is a key element in the development trajectory of villa sites. The abandonment of sites and areas of sites is intimately tied to the transformation of rural settlement. In the majority of cases the lines between abandoned zones and in-use areas are highly blurred and do not easily fit into clear cut definitions ${ }^{88}$. Some of these

\footnotetext{
79 BECHERT 1978.

30 VAN OSSEL 1992, 161-165; VAN OSSEL/OUZOULIAS 2000, 143-145 HEEREN 2018, 140-141.

81 LENZ 1998.

82 VAN OSSEL 1992, 79-84; CHRISTIE 2004, 21-23.

83 VAN OSSEL 1992, LEWIT 1991; 2003; 2005.

84 HEEREN 2017, PERCIVAL 1976, 1992.

85 SCHIFFER 1987, 89.

66 CAMERON/TOMKA 1993; CAMERON 1991; STANTON/MAGNONI 2008, 6-9.

87 SCHIFFER/LAMOTTE 1999, 24-25.

88 SCHIFFER 1996, 40-44; SCARBOROUGH 1989, 415.
} 
a.

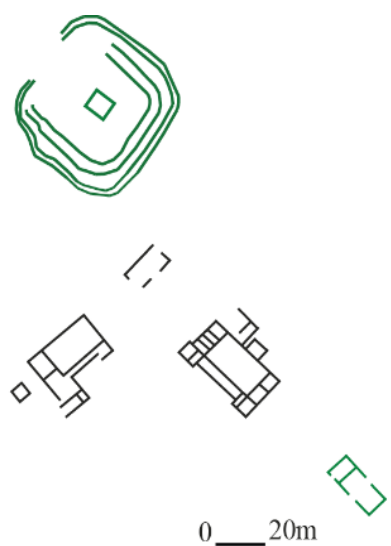

c.

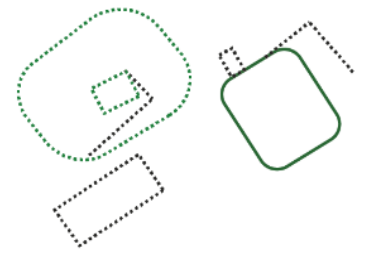

0

e.

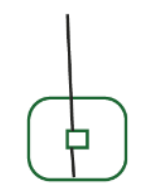<smiles>c1ccc2ccccc2c1</smiles><smiles>C[14CH][14CH]</smiles>

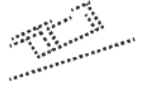
$100 \mathrm{~m}$

g.

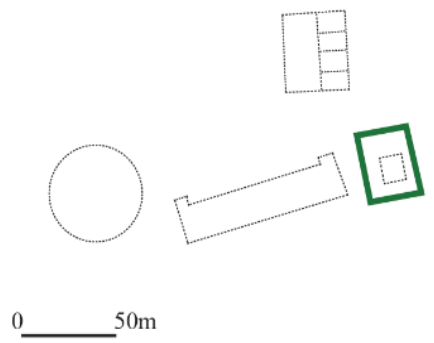

b.

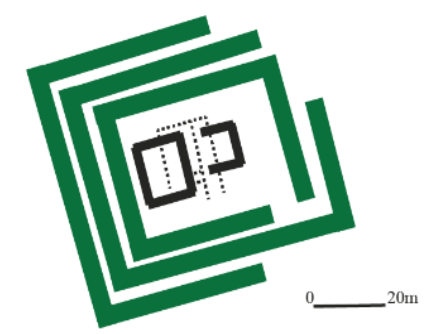

d.
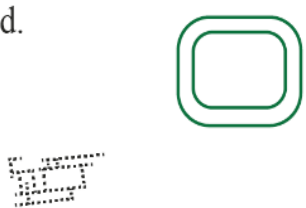

$0 \mathrm{~m}$

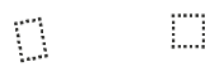
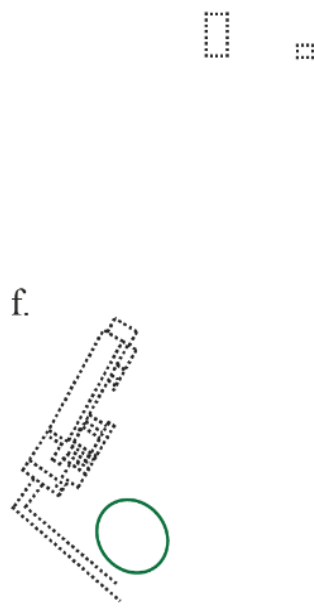
$50 \mathrm{~m}$<smiles>[C+]1[CH]CCC1</smiles>

h.

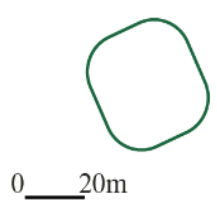

Figure 5: Comparative plans of burgi from the North-Western provinces showing the significant variation in design; a. Rheinbach-Flerzheim, b. Bodenbach, c. Köln-Widdersorf, d. HA303, e. Vettweiß-Froitzheim, f. Rommerkirchen-Nettesheim, g. Wijchen-Tienakker, h. HA224 (Dodd after various). Drawn in Adobe Illustrator 
Table 1. A breakdown of features and material culture associated with classes of transformation (J. Dodd).

\begin{tabular}{|l|l|l|}
\hline Class of Transformation & Archaeological Features & Material Culture \\
\hline Habitational & $\begin{array}{l}\text { postholes, pits, hearths, new floors, wood constructions, } \\
\text { subdividing walls, middens, huts, Grubenhäuser. }\end{array}$ & $\begin{array}{l}\text { domestic pottery, refuge and waste } \\
\text { deposits, organic material deposits }\end{array}$ \\
\hline Productive & $\begin{array}{l}\text { grain driers, threshing floors, metalworking smelters, smithing } \\
\text { hearths, oil/fish production facilities, saltworks, water tanks, } \\
\text { batteries of dolium, kilns. }\end{array}$ & $\begin{array}{l}\text { Industrial quantities of pottery or indus- } \\
\text { trial waste, e.g. metalworking slag }\end{array}$ \\
\hline Funerary & any form of burial, either individually or grouped & grave goods, human remains \\
\hline Cultic & $\begin{array}{l}\text { chapels, oratories and baptisteries. Often only discernable by } \\
\text { overt Christian evidence. }\end{array}$ & $\begin{array}{l}\text { wall plaster with Christian motifs, overt } \\
\text { Christian architectural elements }\end{array}$ \\
\hline Fortification & $\begin{array}{l}\text { burgi, defended enclosures, Speichertürme, fortified } \\
\text { compounds. }\end{array}$ & No associated material culture \\
\hline
\end{tabular}

indeterminate activities, such as stone-robbing, scavenging and partial reuse have been loosely grouped together as 'post abandonment activities'89. Many of these activities are identified as 'squatting' within Roman archaeology. This indicates that these buildings did not immediately enter the archaeological record, but rather continued to play a significant role in local interactions after the end of occupation. This interaction requires a new definition, rejecting Schiffer's simplistic model. This study will define abandonment as 'the end of formal, permanent occupation at a site, or sector of a site'.

This redefinition has been guided by the presence of more advanced theoretical models in other fields of study which have guided the integration of post-abandonment activity into this project. Ethno-archaeological studies, especially in the New World ${ }^{90}$, have highlighted the extremely difficult process of identifying and understanding final floor level assemblages, whilst stressing that the material remains left behind only represents a partial picture of occupation. Such work has also begun to establish that a wide variety of activities occur after the end of formal occupation and can occur in both totally abandoned and sporadically used buildings. The most advanced models have been developed in relation to Mayan archaeology, where significant work has been directed towards understanding different forms of post-abandonment activity on a broad canvas ${ }^{91}$ whilst also identifying different forms of abandonment and its role in the perception of buildings ${ }^{92}$.

A similar approach must be taken in the Roman rural landscape. There is clear evidence that many of these buildings stood well into the Medieval Period ${ }^{93}$. The study of interactions with these buildings has been highly simplified, partly due to their archaeological invisibility. Only in a few simple cases can abandonment be viewed as the single stratigraphic transference of the archaeological horizon into the site record. In almost every case, it is more appropriate to discuss a trajectory, or several competing trajectories, of inter-related uses and perceptions, culminating in the entry of a site into the record.

\footnotetext{
89 SCHIFFER 1996, 207-212.

90 CAMERON/TOMKA 1993; BROOKS/YELLEN 1987; LAMOTTA/ SCHIFFER 1999.

91 STANTON/BROWN/PAGLIARO 2008.

92 STANTON/MAGNOLI 2008.

93 RAHTZ/HARRIS 1956; HOWELL 2000.
}

This paper integrates a more nuanced view of abandonment, with four different grades along a sliding scale, and therefore enabling the categorisation of different forms of post-abandonment activity. Abandonment can be broken down into four broadly differentiating categories, based on different types of reuse and different timescales of abandonment:

- Seasonal: Seasonal re-use is defined as the abandonment of a building for large parts of the year and its reuse for a definable period. This form of abandonment is usually seasonally tied either due to climatic reasons, for example a roofless building would be of limited use in midwinter, or for socio-economic reasons such as cyclical markets or feasting. It is characterised by regular, intense occupational layers separated by periods of natural depositional processes.

- Episodic: Episodic re-use represents the use of a structure on a more or less sporadic basis. It includes a broad array of less formal activities that can occur in unused or decaying buildings. These activities tend to be unplanned and irregular in timescale, with a casual or opportunistic pattern of reuse. They can range from the use of a structure as a temporary shieling for livestock or the use of an unused structure as a dumping ground, to the reuse of a building as shelter or to more generic scavenging or stone robbing. Temporally, these forms of activity can go on for centuries, specifically stone robbing, which often appear not to have been planned or directed in any meaningful way at many sites. This category covers the majority of processes, often archaeologically invisible and constitutes the largest group of post-abandonment activity.

- Near-Permanent: Near-Permanent abandonment represents the reuse or reoccupation of sites after a long period of abandonment. This category of site includes settlements abandoned and reoccupied centuries later. The reuse of a Roman villa abandoned in the $5^{\text {th }}$ century and reoccupied in the $8^{\text {th }}$ century by a Christian centre, Tholey ${ }^{94}$ is one such example. In many cases this can include the use of building materials from the previous occupation as well as looting or pillaging of such material.

- Permanent: Simply put, this is the type of abandonment proposed by Schiffer in 1987 and represents the complete

94 KOLLING 1961. 
and definitive abandonment of a site, without reuse or reoccupation. It would be left as the day that final permanent occupation ended, with the site later shaped by site formation process and modern disturbance. The class of activity includes sites catastrophically destroyed, such as Pompeii and Herculaneum, and those which

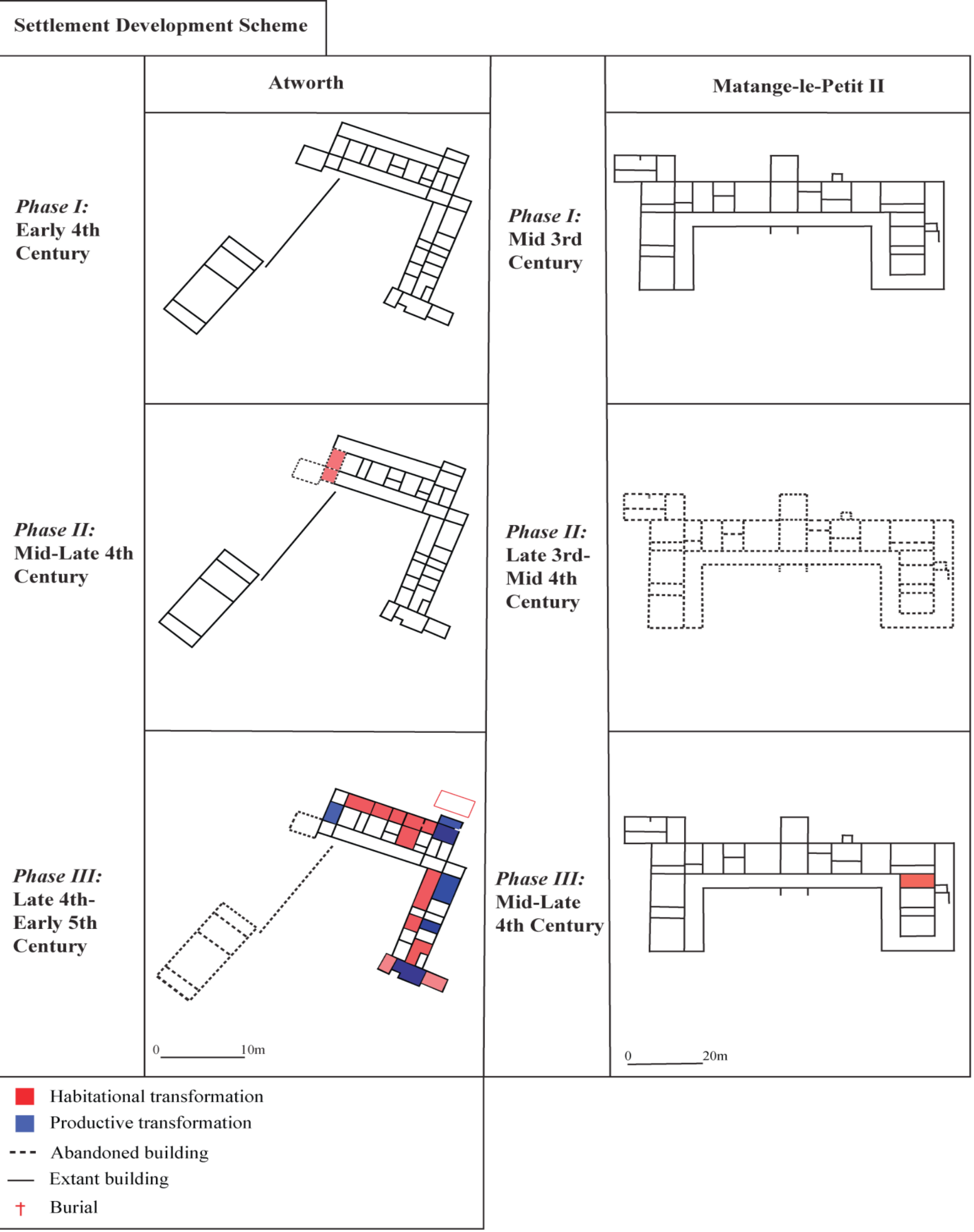

Fig. 6. Two examples of phase plans showing differing trajectories of villas and the increasing reorganisation of space and the eventual abandonment of areas of the complexes (J. Dodd). Drawn in Adobe Illustrator. 
appear to be apparently deliberately destroyed such as the fortress at Inchtuthil ${ }^{95}$. It is only really limited to buildings destroyed beyond any recovery or possible use.

\section{PRACTICAL APPLICATION}

The second aim of this paper is to demonstrate the practical application of this classification system within a settlement development trajectory. A primary problem with all studies of transformation villas is the lack of chronological engagement with the phenomenon ${ }^{96}$. Settlement development trajectories have not been applied to Late Antique villas and subsequently this has left a gap in our understanding of the temporal mechanisms and practicalities of rural change. The theoretical basis for this system has developed from work done on the Late Iron Age and Early Roman Period. Diederick Habermehl developed a schematic system to chart the development of Early Roman rural settlements ${ }^{97}$. The development trajectory used in this study builds on the work done by Habermehl, applying some related methodology. However, unlike Habermehl's study, which could easily chart the development of sites by largescale typological and spatial trajectories, this project cannot adequately achieve the same clarity with transforming villas.

This paper utilises chronological phases to build two individual site biographies (figure 7). These chronological phases are relative to each site, primarily due to the poor stratigraphy of many features and the nature of the chronological evidence. A uniform system of phases across all sites and regions is impossible given the wide variety of biases inherent in the data. The phases in use are generally broad, in most cases spanning half centuries except in specific cases where occupation dates are securely dated. These phases will be used in two ways: firstly they will be employed in combination with a series of colours, which will designate a transformed use of space as illustrated in figure 7 . These colours will demonstrate the changing nature of the site over the Late Roman period and allow both for individual site biographies to be developed and for high-level comparative analysis between sites. Secondly the chronological phases will illustrate the changing size of individual villas throughout Late Antiquity, allowing for meaningful conclusions to be made of chronology and development at these sites.

\section{CONCLUSIONS}

This framework differs from previous studies in a number of ways. Firstly it is tied to a site-specific phasing system, using fixed colours and icons to illustrate the changes of individual site trajectories, similar to the processes pioneered for the Late Iron Age-Early Roman transition by Habermehl. Previous work has only addressed this in the most basic way; broadly shading areas were transformation occurred when setting out site plans ${ }^{98}$. This paper moves forward the theoretical application of settlement trajectories and allows for a more complete analysis of the reorganisation of the social and productive space at rural sites in Late Antiquity. Secondly this framework is designed

\footnotetext{
95 PITTS/ST. JOSEPH 1985, 279-280

96 cf. CHAVARRÍA 2004, 67-68.

97 HABERMEHL 2014, 51-55.

98 CHAVARRÍA 2007, 163-260.
}

for application across Europe, with applicability to all villa settlements across the Western Empire without a regional restriction. It can be used to provide a theoretical platform to expose large scale differences between provinces as well as micro-regional trends in the Roman west and when coupled with modern GIS analysis, it can be used as a powerful tool for mapping rural transformation across the Western Empire, both temporally and spatially.

The large-scale perspective inherent in this also encourages the possibility of integrating the study of transformation between Northern and Southern Europe, traditionally a distinct divide in the study of rural landscapes in Late Antiquity, although this is now somewhat breaking down. However this can only be realistically achieved through the standardisation of terminology, recording and data analysis. Large scale studies in this format can be used to draw conclusions from individual classes of transformation, for example comparing funerary and cultic trends, which have generally been examined on a regional basis ${ }^{99}$. Intraregional studies using this theoretical framework can utilise a data-based system to develop statistical analysis of the patterns and trends of large-scale rural change. A key element of this study has been the development of a standardised terminology, something lacking from most studies of villa transformation, and central to transmitting information as well as developing comparisons and conclusions based on the same standard. This paper has provided a framework to change this and to encourage a further holistic study of rural change across Western Europe, moving beyond regional analysis towards a more modern, integrated framework for villa transformation.

\section{BIBLIOGRAPHY}

\section{Ancient Sources}

Cato De Agricultura, trans. Hooper, W.D. 1934, Marcus Porcius Cato, "On Agriculture"; Marcus Terentius Varro, "On Agriculture” (Loeb Classical Library, Harvard).

Varro Res Rustica, trans. Hooper, W.D. 1934, Marcus Porcius Cato, "On Agriculture"; Marcus Terentius Varro, "On Agriculture”. (Loeb Classical Library, Harvard).

\section{Secondary Sources}

\section{AGACHE 1978}

Agache, R., La Somme pré-romaine et romaine d'après les prospections à basse altitude (Amiens: Mémoires de la Société des antiquaires de Picardie).

\section{BALMELLE 2001}

Balmelle, C., Les demeures aristocratiques d'Aquitaine. Société et culture de l'antiquité tardive dans le Sud-Oeust de la Gaule. (Bordeaux: Aquitania Suppement 10).

\section{BECHERT 1978}

Bechert, T., Wachtturm oder Kornspeicher? Zur Bauweis Spätrömische Burgi, Archäologisches Korrespondenzblatt 8, 127-132

\section{BELL 2007}

Bell, T., The Religious Reuse of Roman Structures in AngloSaxon England [British Archaeological Reports British Series 390] (Oxford: Archaeopress).

BLASQUEZ/GARCIA-GELABERT 1993

Blasquez, J.M/Garcia-Gelabert, M.P., Castulo en el bajo

BELL 2007; CHAVARRÍA 2018; GLIEZE 2017. 
imperio, I Actas Andalucía 2, 289-303.

BRANIGAN 1972

Branigan, K., The End of Roman West, Transactions of the Bristol and Gloucestershire Archaeological Society 91, 117-28.

BRANIGAN 1971

Branigan, K. Pavements and Poverty in the Chiltern Villas, Britannia 2, 106-116.

BROGIOLO/CHAVARRÍA 2008

Brogiolo, Gian Pietro/Alexandra Chavarría Arnau, El final de las villas y las transformaciones del territorio rural en Occidente (siglos V-VIII), in . Fernández Ochoa, C., García Entero, V. and Gil Sendino, F. (eds.) Villas tardorromanas en el occidente del Imperio (Gijon), 93-214.

BROOKS/YELLAN 1987

Brooks, A. S./Yellen, J. E., The Preservation of Activity Areas in the Archaeological Record: Ethnoarchaeological and Archaeological Work in Northwest Ngamiland, Botswana. In: Kent, S. (ed.), Method and Theory for Activity Area Research: An Ethnoarchaeological Approach (Columbia), 63-106.

BRULET 2017

Brulet, R., The Roman army and military defence in Northern Gaul and the Germanic provinces during the Late Empire, in : Roymans N., Heeren S. \& De Clercq W. (eds.), Social Dynamics in the Northwest Frontiers of the Late Roman Empire, (Amsterdam), 39-56.

BRULET 2009

Brulet, R. 2009 (ed.): Les Romains en Wallonie. (Bruxelles: Racine).

BOWES 2001

Bowes, K., ...nec sedere in villam: villa churches, rural piety and the Priscillianist controversy, in Burnes, T.S. and Eadie, J.W. (eds.), Urban centres and Rural Contexts in Late Antiquity (Chicago) 323-348.

CAMERON 1991

Cameron, C., Structure Abandonment in Villages, in Schiffer, M.B. (ed.), Archaeological Method and Theory Vol. III. (UAP, Tuscon) 155-194.

CAMERON/TOMKA 1993

Cameron, C.M./Tomka, S.A., TheAbandonment of Settlements and Regions, Ethnoarchaeological and Archaeological Approaches (Boulder: University of Colorado Press).

CASTRORAO BARBA 2014

Castrorao Barba, A., Continuità topografica in discontinuità funzionale: trasformazioni e riusi delle ville romane in Italia tra III e VIII secolo, The European Journal of Post-Classical Archaeologies 4, 259-296.

CASTRORAO BARBA 2016

Castrorao Barba, A., Sicily before the Muslims. The Transformation of the Roman Villas between Late Antiquity and the Early Middle Ages, Fourth to Eighth Centuries CE, Journal of Transcultural Medieval Studies 3, 145-190.

CHAVARRÍA 2004

Chavarria, A., Interpreting the transformation of late roman villas: the case of Hispania, in N. Christie (ed.), Landscapes of Change. Rural Evolutions in Late Antiquity and the Early Middle Ages, 67-102.

CHAVARRÍA 2007

Chavarria, A. El final de las villas en Hispania (siglos IV-VIII) (Brepols: Turnhout)

CHAVARRÍA 2018

Chavarria, A. People and Landscapes in Northern Italy: Interrogating the burial archaeology of the Early Middle Ages, in; Diarte-Blasco, P. and Christie, N. (eds.), Interpreting Transformations of People and Landscapes in Late Antiquity and the Early Middle Ages (Oxford),163-178.

\section{CHRISTIE 2018}

Christie, N. Introduction: changing data and changing interpretations of the study of transformations in Late Antique Space and Society, in Diarte-Blasco, P. and Christie, N. (eds.), Interpreting Transformations of People and Landscapes in Late Antiquity and the Early Middle Ages (Oxford), ix-X.

\section{CHRISTIE 2004}

Christie, Neil. Landscapes of change in late antiquity and the early middle ages: Themes, directions, and problems, in N. Christie (ed.), Landscapes of Change. Rural Evolutions in Late Antiquity and the Early Middle Ages (Aldershot), 1-37.

\section{CHRISTIE 1992}

Christie, N., The survival of Roman settlement along the Middle Danube: Pannonia from the fourth to the tenth century AD, Oxford Journal of Archaeology 11, 317-339.

COLLINS 2012

Collins, R., Hadrian's Wall and the End of Empire: The Roman Frontier in the 4th and 5th Centuries (London-New York, Routledge).

COLLINS 2017

Collins, R., Decline, collapse, or transformation? The case for the northern frontier of Britannia, Roymans N., Heeren S. \& De Clercq W. (eds.), Social Dynamics in the Northwest Frontiers of the Late Roman Empire, (Amsterdam), 203-220

\section{CORNEY 2003}

Corney, M., The Roman Villa at Bradford on Avon: The Investigations of 2002 (Trowbridge, Ex Libris).

\section{CORNEY 2004}

Corney, M., The Roman Villa at Bradford on Avon: The Investigations of 2003 (Trowbridge: Ex Libris).

CROWLY 2011

Crowly, L., Dying in a Material world. Self-representation and its implications in privileged mortunary contexts in the Roman villa landscapes between Bavay and Cologne. Unpublished PhD Thesis, VU Amsterdam.

DANIELS 1966

Daniels, C.M., Excavation on the site of the Roman Villa at Southwell, 1959, Transactions of the Thoroton Society 70, 13-33

DARK 2005

Dark, K., The archaeological implications of fourth- and fifth-century descriptions of villas in the northwest provinces of the Roman Empire, Historia 54, 331-342

DODD 2014

Dodd, J., A Preliminary Quantification of 'Squatter' Occupation in the Villas of Late Roman Britain. Unpublished MA Thesis, University of Newcastle-upon-Tyne.

DUVAL 1982

Duval, N., Quelques remarques sur les l'églises-halles, Aquileia nel IV Secolo [XII Settimana di studi aquileiesi, 30aprile-5 maggio 1981. 2, 399-412.

ELLIS 1988

Ellis, S.P., The End of the Roman House, American Journal of Archaeology 92, 565-576.

FLEMING 2012

Fleming, R., Recycling in Britain after the fall of Rome's metal economy, Past and Present 217, 1-45.

GANDINI 2008

Gandini, C., Des campagnes gauloises aux campagnes de l'Antiquité tardive : la dynamique de l'habitat rural dans la cité des Bituriges Cubi (IIe s. av. J.-C.-VIIe s. ap. J.-C.) (Paris, Gallia supplement).

GARCÍA GELABERT/GARÍA DÍAZ 1997

García Gelabert, P./García Díaz, M., El asentamiento romano de Catarroja: aproximación a su estudio en Espacio, 
tiempo y forma, Historia Antigua, 10, 351-374.

GORGES 1979

Gorges, J.-G., Les villas hispano-romaines: Inventaire et problématique archéologiques. (Paris: Publications du Centre Pierre Paris).

GLIEZE 2017

Glieze, Y., Sepultures des marges et sepultures marginales. Sur quelques examples medieaux de la moite sud de la France. In Bis-Wach, C. and Theune, C. (eds.) Religion, Cults and Rituals in the Medieval Rural Environment, ruralia IX (Leiden), 201-204.

GRENIER 1934

Grenier, A., Archéologie gallo-romaine (Manuel d'archéologie préhistorique, celtique et gallo-romaine de Joseph Déchelette, VI). Deuxième partie : L'archéologie du sol (Paris: Picard).

HABERMEHL 2014

Habermehl, D., Settling in a Changing World: Villa Development in the Northern Provinces of the Roman Empire (Amsterdam: Amsterdam Archaeological Studies).

HEEREN 2015

Heeren, S., The depopulation of the Lower Rhine region in the 3rd century. An archaeological perspective, Roymans, N., Derks. T. and Hiddink, H. (eds.), The Roman villa of Hoogeloon and the archaeology of the periphery. (Amsterdam) 271-294.

HEEREN 2016

Heeren, S., The theory of 'Limesfall' and the material culture of the late 3rd century, Germania 94, 185-209.

HEEREN 2017

Heeren, S., From Germania Inferior to Germania Secunda and Beyond: A case study for migration, transformation and decline, Roymans N., Heeren S. \& De Clercq W. (eds.), Social Dynamics in the Northwest Frontiers of the Late Roman Empire (Amsterdam), 149-178

HEEREN 2018

Heeren, S., Military Might for a depopulated region? Interpreting the Archaeology of the Lower Rhine Area in the Late Roman Period, in; Diarte-Blasco, P. and Christie, N. (eds.), Interpreting Transformations of People and Landscapes in Late Antiquity and the Early Middle Ages (Oxford),137-148.

HEIJMANS/GUYON 2007

Heijmans M./Guyon, J., “Antiquité Tardive, Haut Moyen Âge Et Premiers Temps Chrétiens en Gaule Méridionale: Seconde Partie: Monde Rural, Échanges Et Consommation." Gallia 64, 5-10.

HEIMBERG 2002/2003

Heimberg, U., Römische villen an Rhein und Maas, Bonner Jahrbuch 202/203, 58-146

HENRICH 2010

Henrich, P., Die römische Nekrople und sie Villenanlage von Duppach-Weiermühle Vulkaneifel [Trierer Zeitschrift Beiheft 33], (Trier).

HENRICH 2016/2017

Henrich, P., Die befestigte Villa von Bodenbach (Landkreis Vulkaneifel) im Kontext der spätantiken Befestigungen Nordgalliens und Niedergermaniens, Trierer Zeitschrift 79/80, 231-283.

HETTNER 1893

Hettner, F., Die Römischen Steindenkmäler des Provinzialmuseums Trier (Trier: Provinzialmuseums Trier).

HINGLEY 1989

Hingley, R., Rural Settlement in Roman Britain (Seaby, Oxford).

HINLEY 2005

Hingley, R., Globalizing Roman Culture: Unity, Diversity and Empire (London: Routledge).

\section{HODDER/MILLET 1980}

Hodder, I.R./Millett, M., 'Romano-British Villas and Towns: A systematic analysis', World Archaeology 12, 69-76.

HOWELL 2000

Howell, R., The Demolition of the Roman Tetrapylon in Caerleon: An erasure of memory? Oxford Journal of Archaeology 19, 387-395.

JOHNSON 1983

Johnson, S., Late Roman Fortifications (London: Batesford).

KOETHE 1940

Koethe, H., Die Bäder römischer Villen im Trierer Bezirk, Bericht der Römisch-Germanischen Komission 30, 43-131.

LANDSTÄTTER/PÜLZ 2007

Landstätter, S./A. Pülz., Ephesus in the Late Roman and Byzantine Period: Changesin Its Urban Character from the Third to the Seventh Century AD, Proceedings of the British Academy 141, 391-434.

LE MAHO 1994

Le Maho, J., La reutilisation funeraire des edifices antiques en Normandie au cours du haut Moyen-Age, in Fixot, M. and Zadora-Rio, E. (eds.), L'environnement des eglises et la topographie religieuse des campanges medievales (Paris), 10-21.

LENZ 1998

Lenz, K-H., Siedlungen der römischen Kaiserzeit auf der Aldenhovener Platte (Köln: Rheinland-Verlag).

LEWIT 1991

Lewit, T., Agricultural Production in the Roman Economy AD 200-400 [British Archaeological Reports International Series 568] (Oxford: Archaeopress).

\section{LEWIT 2001}

Lewit, T. ,Changing concepts of Late Antiquity: The decline and fall of Gibbonism, Bulletin de l'Antiquité Tardive 10, 33-37.

\section{LEWIT 2003}

Lewit, T., "Vanishing Villas": What happened to the elite rural habitations in the west in the 5th-6th centuries? Journal of Roman Archaeology 16: 260-274.

LEWIT 2004

Lewit, T., Villas, Farms and the Late Roman Rural Economy (third to fifth centuries AD), [British Archaeological Reports International Series 568] (Oxford: Archaeopress).

LEWIT 2005

Lewit, T., Bones in the Bathhouse: Re-evaluating squatter occupation at 5 th to 6 th century villas, in Brogiolo, G.P., Chavarría Arnau, A., and Valenti, M. (eds.), Dopo la fine delle ville: le campagne dal VI al IX seco. (Mantova), 251-262

LEWIT/CHAVARRÍA 2004

Lewit, T./Chavarría, A., Recent Archaeological Research on the Late-Antique Countryside: A Bibliographic Essay in Lavan, L., Bowden, W. and Machado, C. (eds.) Recent Research on the Late Antique Countryside. Late Antique Archaeology 2 (Leiden), 1-51

LIVERSAGE et alii 1973

Liversidge, J./Smith, D. J./Stead, I. M./Rigby, V., Brantingham, Roman Villa: Discoveries in 1962, Britannia 4, 84-106.

MALONEY/HALE 1996

Maloney, S.J./Hale, J.R. The villa of Torre de Palma (Alto Alentejo), Journal of Roman Archaeology 9, 275-294.

MATTINGLEY 1995

Mattingley, D., Tripolitania. (London: Batsford).

MATTINGLEY 2006

Mattingley, D., An Imperial Possession: Britain in the Roman Empire 54BC - AD409 (London: Penguin).

MEATES 1979

Meates. G.W., The Roman villa site at Lullingstone, Kent (Canterbury: Kent Archaeological Society).

METZLER/ZIMMER/BAKKER 1981 
Metzler, J./Zimmer, J./Bakker, L.,Ausgrabungen inEchternach. (Publications du le ministeré culturelle, Luxemburg).

MONTFRIN 1998

Montfrin, F., L'établissement material de l'église aux Ve et Vie siècles, Histoire du Christiansme des origines á nos jours III: Les églises d' Orient et d' Occident, 959-1014.

MUNRO 2010

Munro, B., Recycling in Late Roman Villas in Southern Italy: Reappraising Hearths and Kilns in Final Occupation Phases, Mousieion 10, 17-242

NASH-WILLIAMS 1953

Nash-Williams, V.E., The Roman Villa at Llantwit major in Glamorgan, Archaelogia Cambrensis 102, 89-163.

O’NEILL 1933

O'Neill, B. H. St. J., The Roman Villa at Magor Farm, Near Camborne, Cornwall, Journal of the British Archaeological Association 39, 117-175

ORETAGO 1977

Oretego, T., La villa romana de "Los Quintanares" en el término de Rioseco (Soria), in Almagro, M. (ed.) Segovia y la Arqueología Romana, 285-292.

PAYNE 1897

Payne, G., The Roman Villa at Darenth, Archaeologia Cantiana 22, 49-84.

PELLECUER/POMERADES 2001

Pellecuer, C./Pomerades, H., Crise, survie ou adaption de la villa romaine en Narbonnaise premiére? Contribution des récentes recherches de terrain en Languedoc-Roussillion, in Ouzoulias, P./Pellecuer, C./Raunaud, C./Van Ossel, P./Garmy, P. (eds.), Les Campagnes de la Gaule á la fin de l'Antiquité, (Antibes), 503-534.

PETTS 1997

Petts, D., 'Elite Settlements in the Roman and Sub-Roman periods': in Meadows, K. (ed.), Proceedings of the Sixth Theoretical Roman Archaeology Conference (TRAC), Sheffield, 1996 (London: TRAC Publications)

PERCIVAL 1976

Percival, J., The Roman Villa: A Historical Introduction. (Manchester: Batesford)

PERCIVAL 1997

Percival, J., Villas and Monasteries in Late Roman Gaul, The Journal of Ecclesiastical History 48, 1-21

PITTS/ST. JOSEPH 1985

Pitts, L.F./St. Joseph, J. K. S., Inchtuthil: the Roman Legionary Fortress Excavations, 1952-6 [Britannia Monograph 1] (London).

PUERTAS 1972

Puertas, R., Trabajos de planimetría y excavación en la 'villa Fortunatus' Fraga (Huesca), Noticiario Arqueológico Hispánico 1, 71-81.

RAHTZ/HARRIS 1956

Rahtz, P./Harris, L.G., The temple well and other buildings at Pagans Hill, Chew Stoke, North Somersetshire, in Proceedings of the Somersetshire Archaeological and Natural History Society 101, 25-51.

RAMOS FLOQUE 1960

Ramos Floque, A., Las invasiones germánicas en la provincial de Alicante (siglos III y $\mathrm{V}$ de J.C.). (Alicante: Instituto de Estudios Alicantinos).

RASCÓN MARQUÉS/MÉNDEZ MADARIAGA/DÍAZ DEL RIO ESPAŇOL 1991

Rascón Marqués, S./Méndez Madariaga, A/Díaz del Rio Espaňol, P., La reocupación del mosaic del auriga victorioso en la villa romana de El Val (Alcalá de Henares). Un studio de microespacio, Arqueología, Paleontología y Etnografía 1, 181-200.

\section{RAYNAUD 2018}

Raynaud, C., The Countryside of Southern Gaul from the $4^{\text {th }}$ to the $7^{\text {th }}$ centuries AD. Settlement, Landscapes and Society, in Diarte-Blasco, P. and Christie, N. (eds.), Interpreting Transformations of People and Landscapes in Late Antiquity and the Early Middle Ages (Oxford), 43-52.

RIN 2009

Rind, M., Römische Villen in Nordafrika: Untersuchungen zu Architektur und Wirtschaftsweise. (British Archaeological Reports 2012, Oxford).

RIPOLL/ARCE 2000

Ripoll, G./Arce, J., The Transformation and End of Roman Villae in the West (Fourth-Seventh Centuries: Problems and Perspectives), in Brogiolo, G.P., Gauthier, N. and Christie, N. (eds.), Towns and their Territories between Late Antiquity and the Early Middle Ages (Leiden), 63-114.

RIVET 1969

Rivet, A.L.F., 'Social and Economic Aspects', in , Rivet, A.L.F. (ed.), The Roman Villa in Britain (London), 173-216.

RÉCHIN 2006

Réchin F., Nouveaux regards sur les villae d'Aquitaine: bâtiments de vie etdrexploitation, domaines et postérités médiévales, (Publications de l'Université de Pau. Pau).

RODGERS 2011

Rodgers, A., Late Roman Towns in Britain: Rethinking Change and Decline (Cambridge: Cambridge University Press).

ROYMANS 1996

Roymans, N., From the Sword to the Plough: Three Studies on the Earliest Romanisation of Northern Gaul (Amsterdam: Amsterdam Archaeological Studies).

ROYMANS/DERKS 2011

Roymans, N./Derks, T., Studying Roman Villa Landscapes in the 21st century: A multi-dimensional approach, in: Roymans, N./ Derks, T. (eds.), Villa Landscapes in the Roman North (Amsterdam), 1-44.

SÁNCHEZ 1997

Sánchez, G.S., Intervención en un solar de la Constantino, no.25, Mérida 1, 178-186.

SCARBOROUGH 1989

Scarborough, V., Site Structures of a village of Late Pithouse-Early Pueblo period in New Mexico, Journal of Field Archaeology 16, 405-425.

SCHIFFER 1987

Schiffer, M.B., Formation processes of the archaeological record (Albuquerque: University of Utah Press).

SCHIFFER 1996

Schiffer, M.B., Some relationships between behavioural and evolutionary archaeologies. American Antiquity 61, 643-662.

SCHIFFER/LAMOTTE 1999

Schiffer, M./LaMotta, V. M., Formation processes of House Floor Assemblages, in Allison, P.M. (eds.), The Archaeology of Household Activities (New York), 19-29.

SCHNEIDER 2007

Schneider, L., Structures du peuplement et formes de l'habitat dans les campagnes du Sud-Est de la France de l'Antiquité au Moyen Age (IV-VIIIe s.), Gallia 64, 11-56

SLOFSTRA 1983

Slofstra, J. An anthropological approach to the study of Romanization processes, in Brandt, R.W. and Slofstra, J. (eds), Roman and native in the low countries. Spheres of interaction (Oxford), 71-104.

SLOFSTRA 1991

Slofstra, J., hanging settlement systems in the MeuseDemer-Scheldt area during the early Roman period, in Roymans, N. and Theuws, F. (eds.), Images of the past. Studies 
on ancient societies in Northwestern Europe (Amsterdam), 131-199.

SLOFSTRA/BRAND 1983

Slofstra, J./Brand, R. (eds.), Roman and native in the Low Countries: spheres of interaction. [British Archaeological Reports International Series 184] (Oxford: Archaeopress).

SMITH et alii 2016

Smith, A./Allen M./Brindle T./Fulford, M., New Visions of the Roman countryside Volume 1: The Rural Settlement of Roman Britain (London: Britannia Monographs)

STANTON/MAGNONI 2008

Stanton, T.W./Magnoni, A. (eds.), Ruins of the Past, The Use and Perception of Abandoned Structures in the Maya Lowlands (Denver: University of Colorado).

STANTON/BROWN/PAGLIARO 2008

Stanton, T. W/Brown, M./Pagliaro, J. B., Garbage of the Gods? Squatters, Refuse Disposal, and Termination Rituals among the Ancient Maya', Latin American Antiquity 19, 227-247.

SPEED 2014

Speed, G., Towns in the Dark? Urban Transformations from Late Roman Britain to Anglo-Saxon England. (Leicester: Archaeopress)

TARACENA 1950

Taracena, B., Las invasions germánicas en Espaňa durante la segunda mitad del siglo III de J.C., Primer Congreso Internacional de Pireneistas del Instituto de Estudios Pirenaicos, 4-13.

VAN OSSEL 1992

Van Ossel, P., Etablissment ruraux de L'Antiquité Tardive dans le nord de la Gaule [Supplément Gallia 51], (Paris).

VAN OSSEL 2006

Van Ossel, P., Rural impoverishment in Northern Gaul at the end of Antiquity: The Contribution of Archaeology, in Bowden, W., Guttridge, A. and Machado, C. (eds.), Social and Political Life in Late Antiquity (Leiden), 533-565.

\section{VAN OSSEL/OUZOULIAS}

Van Ossel, P./Ouzoulias, P., Rural settlement economy in Northern Gaul in the Late Empire: an overview and assessment, Journal of Roman Archaeology 13, 133-160.

\section{VON PETRIKOVITS 1971}

Von Petrikovits, H. Fortifications in the North-Western Roman Empire from the Third to the Fifth Centuries A.D., The Journal of Roman Studies 61, 178-218.

\section{WEBSTER 1969}

Webster, G., The future of villa studies, in Rivet, A.L.F. (ed.), The Roman Villa in Britain (Batesford, London), 217-249.

WIGHTMAN 1985

Wightman, E., Gallia Belgica (London: Batsford).

WHEELER/WHEELER 1936

Wheeler, R. E. M./Wheeler, T. V., Verulamium: A Belgic and two Roman Cities (Oxford: Reports of the Society of Antiquaries)

WHITE 1990

White, R. H., Excavations on the Site of the Baths Basilica. From Roman Viroconium to Medieval Wroxeter. (Wroxeter: West Mercian Archaeological Consultants).

WILMOTT 1997

Wilmott, T., Birdoswald: Excavations of a Roman Fort on Hadrian's Wall and its successor settlements 1987-1992, (London: English Heritage).

WILLIS/CARNE 2013

Willis, S./Carne, P., A Roman Villa at the Edge of Empire. Research Report (Durham:Council for British Archaeology)).

\section{WRIGHT 1941}

Wright, R.P., Roman Britain in 1940: I. Sites Explored: II. Inscriptions, Journal of Roman Studies 31, 128-148.

\section{WOOLF 1998}

Woolf, G., Becoming Roman: The origins of provincial civilization in Gaul. (Cambridge: Cambridge University Press). 